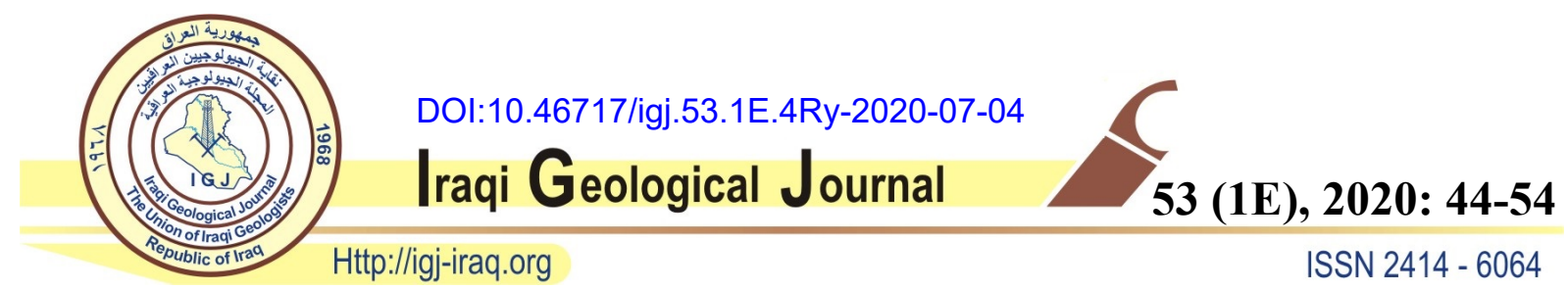

\title{
ENGINEERING PERFORMANCE OF SELECTED PROPERTIES OF UMM AL-JAMAL BASALTIC ROCKS, NE JORDAN
}

\author{
${ }^{1}$ Qaher Al-Qadi, ${ }^{2}$ Ahmad Al-Malabeh*, ${ }^{2}$ Raja' Hamed and ${ }^{2}$ Khaled Al-Zawahreh \\ ${ }^{1}$ Department of Earth and Environmental Sciences, The Hashemite University, Zarqa, Jordan \\ ${ }^{2}$ Department of Physics, Yarmouk University. Irbid, Jordan \\ *E-mail: kaisermalabite@yahoo.com \\ Received: 1 August 2019; accepted: 10 May 2020
}

\begin{abstract}
The aim of this research is to study the engineering properties of Umm Al-Jamal basalt rocks. These rocks are mainly of Miocene to Holocene age. Umm Al-Jamal basalt consists of five thickly basaltic flows with a total thickness of up to $50 \mathrm{~m}$. The basaltic rocks in the study area have attractive engineering properties, the rocks have high specific gravity, high apparent specific gravity and low absorption with average values 0.82-1.66 and $1.27 \%$, respectively. They also have medium porosity class $C$ with an average of $1.46 \%$ and high unit weight with an average of $2.60 \mathrm{~g} / \mathrm{m}^{3}$, respectively. The studied rocks are classified as high ultrasonic wave velocity of class 4 which gives an average of $4514 \mathrm{~m} / \mathrm{s}$, uniaxial compressive strength, (98.5 and 106.9 MPa), flexture strength (29- 23.5 MPa), tensile strength (9.5-10.9 MPa), The calculated abration ratio of 100/500 shows an average of $0.25 \%$ which is classified as medium strength, class $C$, and very high slake durability (98.8-99.3 MPa). The given results fit well with the classification schemes of the international specification. The physical and mechanical properties of the studied basalt are the main determinant in choosing several techniques. It is concluded that the basalt rocks of Umm Al-Jamal can be utilized in the construction purposes as dimension stone and as normal aggregates. Finally, it is recommended to take this study in consideration in any conservation or restoration processes at Umm Al-Jamal archaeological city.
\end{abstract}

Keywords: Umm Al-Jamal; Basalt; Physical and mechanical properties; Constructions

\section{INTRODUCTION}

Harrat Al-Shaam spreads among Syria, Jordan and Saudi Arabia. It represents a giant basaltic field on the Arabian plate and occupies a total area of 50,000 $\mathrm{km}^{2}$ (Coleman and McGuire, 1988; Al-Malabeh, 1994, Roobol et al., 2002, and Camp and Roobol, 1989). In Jordan, the segment of the Harrat is called Jordanian Harrat (Smadi et al., 2018) and covers 
an area of 12,000 $\mathrm{km}^{2}$, (Fig. 1). Chemical results of the basalt rocks in the Jordanian Harrrat (e.g., Barberi et al., 1979, Al-Malabeh, 1993; and Al-Malabeh et al., 2002) indicate that the rocks are mainly of alkali olivine types. The basalt rocks in Jordanian Harrat are mainly of Miocene to Holocene in age.

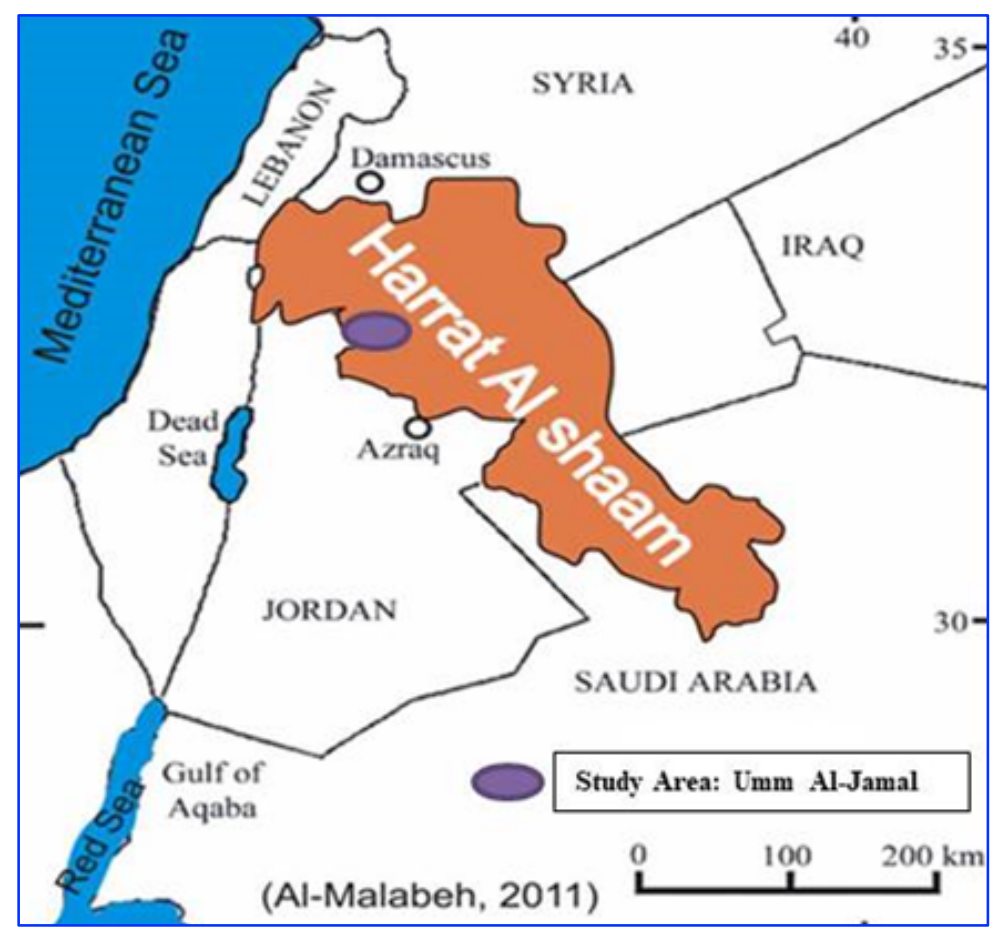

Fig. 1. Location map of Harrat Al-Shaam and the study area

Extensive amounts of basalts are occurring in Umm Al-Jamal. These basalts have been used by Greek, Roman-Byzantine and Islamic periods (Al-Malabeh, 2010 and Abu-Mahfouz et al., 2016). Huge cities are built of these materials they proved excellent ability and capacity to design. Moreover, they exhibit huge stability through the history (Rababeh et al., 2010). The basalts are of Miocene to Holocene age (Fig. 2). They always reported in basaltic articles in general without any detailed physical and mechanical properties. The aim of the present study is to determine the engineering properties of these basaltic rocks.

\section{STUDY AREA}

The investigated area lies in the northeast parts of Jordan; within the Mafraq government, approximately $20 \mathrm{~km}$ northeast of Al-Mafraq city. The Umm Al-Jamal basalt is almost accessible through several asphaltic and track roads that already exist to connect several towns in the area. The Umm Al-Jamal lies in the eastern parts of the Jordanian Harrat, near the Jordanian-Syrian borders (Fig. 2). The elevation is about $800 \mathrm{~m}$ (a.m.s.l) and covers an area of about $10 \mathrm{~km}^{2}$. It was developed due to intermittent eruption from deep-seated faults in form of 5 successive basaltic pahoehoe flows with a total thickness of $50 \mathrm{~m}$ (Fig. 2). 


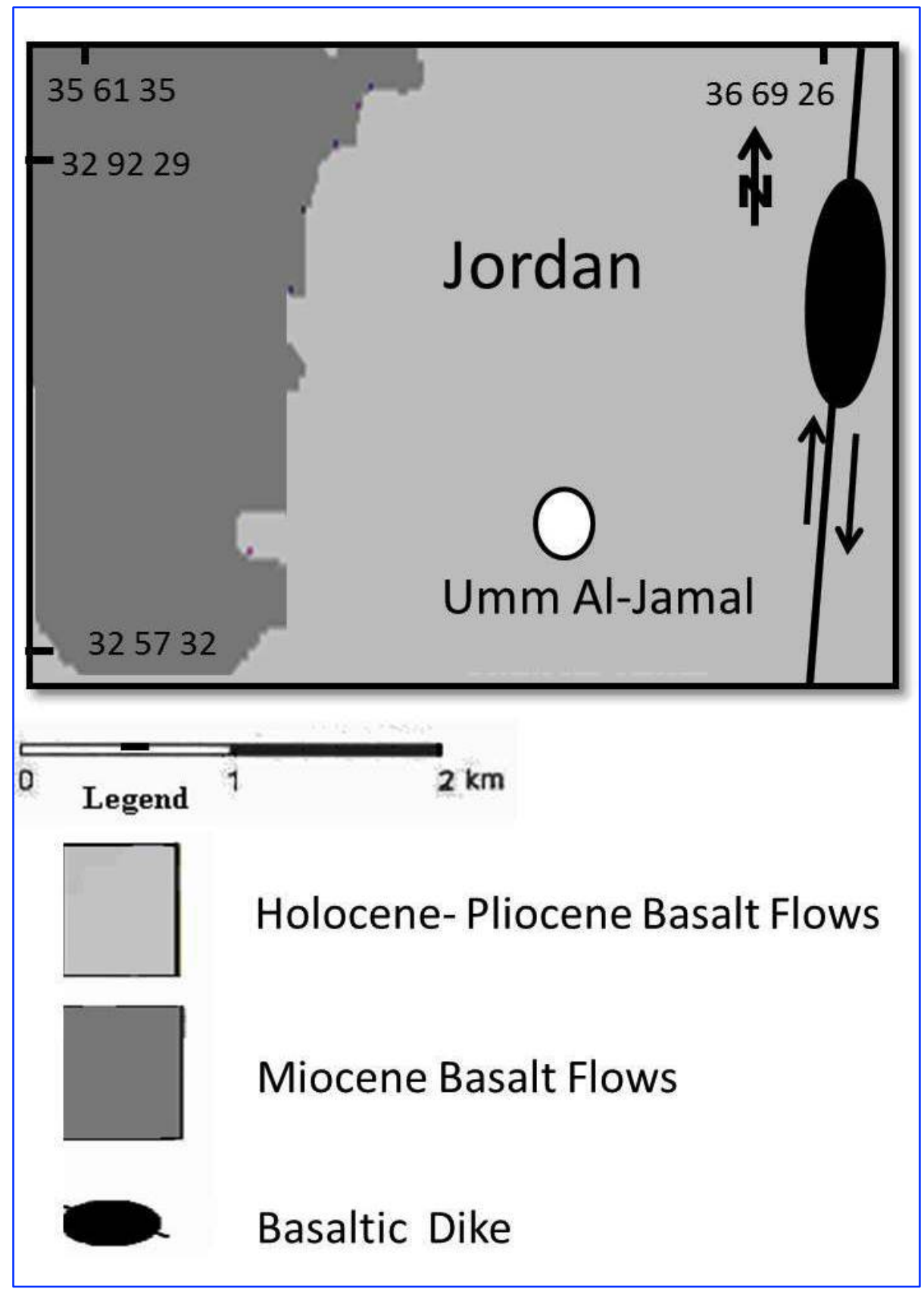

Fig. 2. Geological map of Umm Al-Jamal area

\section{MATERIALS AND METHODS}

Ten representative samples were collected and studied for the purposes of engineering: physical and mechanical prosperities several tests are carried out at the Department of Civil Engineering at Jordan University for Science and Technology. The conducted tests are explained in the results. All these tests were conducted according to the specifications of (e.g., ASTM (2008), ISRM (1978) and IAEG (1986), the different tests and their references are listed in Tables (1 and 2). 
Table 1. Physical properties tests

\begin{tabular}{|c|c|c|}
\hline Rock Parameter and Reference & Test Formaula or Machin & \\
\hline $\begin{array}{l}\text { Bulk specific gravity } \\
\text { ASTM (2008) }\end{array}$ & $\mathrm{GSB}=\mathrm{Wd} /(\mathrm{Wssd}-\mathrm{Wsat})$ & \multirow{3}{*}{$\begin{array}{l}\text { where: } \\
\text { Wd = weight of oven-dried sample (gm). } \\
\text { Wssd = weight of saturated with water } \\
\text { surface dry sample (gm). } \\
\text { Wsat = weight of saturated sample (gm). }\end{array}$} \\
\hline $\begin{array}{l}\text { Apparent specific gravity } \\
\text { ASTM (2008) }\end{array}$ & $\mathrm{GSA}=\mathrm{Wd} /(\mathrm{Wd}-\mathrm{Wsat})$ & \\
\hline $\begin{array}{l}\text { Absorption } \% \\
\text { ASTM (2008) }\end{array}$ & $\begin{array}{l}\mathrm{A}=(\mathrm{Wssd}-\mathrm{Wd}) / \mathrm{Wd} \times \\
100\end{array}$ & \\
\hline $\begin{array}{l}\text { Dry unit weight }\left(\mathrm{gm} / \mathrm{cm}^{3}\right) \\
\text { (Derucher \& Heins, 1981) }\end{array}$ & \multicolumn{2}{|c|}{$\begin{array}{l}\gamma \mathrm{d} 1 / 4 \mathrm{Wd} . \mathrm{Vt} \\
\text { where: } \\
\gamma \mathrm{d}=\text { dry unit weight }\left(\mathrm{g} / \mathrm{cm}^{3}\right) \text {. } \\
\mathrm{Wd}=\text { weight of the oven-dried sample }(\mathrm{g}) . \\
\mathrm{Vt}=\text { total volume of basalt sample }\left(\mathrm{cm}^{3}\right)\left(\mathrm{Vt}=(\pi / 4) \times D^{2} \times h\right) \text {. }\end{array}$} \\
\hline $\begin{array}{l}\text { Porosity (n) } \\
\text { (Brown, 1981) }\end{array}$ & \multicolumn{2}{|c|}{$\begin{array}{l}\mathrm{n}=(\mathrm{Vv} / \mathrm{Vt}) \times 100 \\
\text { where: } \\
\mathrm{Vv}=\text { volume of voids or pores }\left(\mathrm{cm}^{3}\right) . \mathrm{Vt}=\text { total external volume }\left(\mathrm{cm}^{3}\right) \text {. }\end{array}$} \\
\hline $\begin{array}{l}\text { Ultra-sonic wave (m/s) velocity } \\
\text { (Obert and Duvall, 1967) }\end{array}$ & \multicolumn{2}{|l|}{ UPV machine } \\
\hline
\end{tabular}

\section{RESULTS AND DISCUSSION}

\section{Physical properties Tests}

The experimental tests conducted on the samples show that the average values of specific gravity, apparent specific gravity and absorption (\%) are: 2.73, 2.64 and 1.27\%, respectively, (Table 3). These properties are varied slightly in the investigated samples which may be related to the presence of vesicles in cores. Porosity has an average of $1.46 \%$, which related to class $\mathrm{C}$ of medium porous, based on the rock classification criterion given by Jumikis (1983). Specific gravity has moderaly positive correlations with the absorption where $\mathrm{R}^{2}=0.69$ (Fig. 3a), a positive correlations with porosity, $\mathrm{R}^{2}=0.65$ (Fig. $3 \mathrm{~b}$ ) and a positive correlations with absorption $\mathrm{R}^{2}=0.63$ (Fig. 3c). These results do not show considerable similarity with the results obtained by Abu-Mahfouz et al. (2016). Specific gravity has positive correlations with unit weight $\mathrm{gm} / \mathrm{cm} 3, \mathrm{R}^{2}=0.61$ (Fig. 3.d). Moreover, it is evident that the considerable dry unit weight with values between 2.58 and $2.67 \mathrm{gm} / \mathrm{cm} 3$. The high unit weight and medium porosity may be attributed to the crystalline nature of the rocks. The Umm Jamal is classified as a high ultrasonic wave velocity which gives an average of 4514 $\mathrm{m} / \mathrm{s}$ (Table 3). Based on this criterion, set by the IAEG (1986), the tested samples lie in class 4. The correlation coefficient diagrams in the above-mentioned figures show that the density has a significant effect on absorption for the basalt rocks. Furthermore, since porosity is the major factor affecting absorption, This correlation indicates that the internal structures of basalt rocks in which micro-cracks and pores contribute significantly (Al-Malabeh and AlKharabsheh, 2002). 
Table 2. Mechanical properties tests

\begin{tabular}{|c|c|}
\hline $\begin{array}{c}\text { Rock Parameter and } \\
\text { Reference }\end{array}$ & Test Formaula Or Machine Initials Description \\
\hline $\begin{array}{l}\text { Compressive strength (MPa) } \\
\text { (Obert and Duvall 1966) }\end{array}$ & $\begin{array}{l}\sigma c=\mathrm{Fo} / \mathrm{A} \\
\text { where: } \\
\sigma \mathrm{c}=\text { compressive strength axial load }(\mathrm{MPa}) . \\
\text { Fo }=\text { the maximum applied load }(\mathrm{N}) . \\
\mathrm{A}=\text { exposed area of the specimen }(\mathrm{mm})\end{array}$ \\
\hline $\begin{array}{l}\text { Slake durability index (Id1 } \\
\text { and Id2) } \\
\text { (Brown 1981) }\end{array}$ & $\begin{array}{l}\text { Id } 1=(\mathrm{W} 2 /(\mathrm{W} 1) \times 100 \% \\
\mathrm{Id} 2=(\mathrm{W} 3 / \mathrm{W} 1) \times 100 \% \\
\text { where: } \\
\mathrm{W} 1=\text { the initial weight of the sample }(\mathrm{g}) . \\
\mathrm{W} 2=\text { the weight of the sample after the first cycle }(\mathrm{g}) . \mathrm{W} 3=\text { the } \\
\text { weight of the sample after the second cycle }(\mathrm{g})\end{array}$ \\
\hline $\begin{array}{l}\text { Rock hardness (Schmidt } \\
\text { hammer, H.R.) } \\
\text { (Deere \& Miller, 1966) }\end{array}$ & Spring-driven steel hammer \\
\hline $\begin{array}{l}\text { Point load (MPa): (Is) } \\
\text { (Farmer, 1983) }\end{array}$ & $\begin{array}{l}\text { Is }=\mathrm{P} / \mathrm{D} 2 \\
\text { Where: } \\
\mathrm{P}=\text { failure load }(\mathrm{N}) \\
\mathrm{D}=\text { core diameter, } \mathrm{mm} .\end{array}$ \\
\hline $\begin{array}{l}\text { Los Angeles Abrasion (\%) } \\
\text { ASTM (2008) }\end{array}$ & $\begin{array}{l}\%(\mathrm{~A}-\mathrm{B}) * \mathrm{~B} \\
\text { Where: } \\
\mathrm{A}=\text { weight of sample- } 1 \\
\mathrm{~B}=\text { weight of sample- } 2\end{array}$ \\
\hline $\begin{array}{l}\text { Indirect tensile strength (MPa) } \\
\text { (ISRM, 1978) }\end{array}$ & $\begin{array}{l}\sigma \mathrm{N}=\mathrm{M} \max / \mathrm{S} \\
\text { where: } \\
\mathrm{M}_{\max }=\text { the maximum moment at the peak load } \\
\mathrm{S}=\text { Elastic selection modulus }\end{array}$ \\
\hline $\begin{array}{l}\text { Flexural strength (MPa) } \\
\text { ASTM (2008) }\end{array}$ & $\begin{array}{l}\sigma=\mathrm{F} / \mathrm{bd} \\
\text { where: } \\
\mathrm{F}=\text { is the axial load (force) at the fracture point } \\
\mathrm{b}=\text { is width } \\
\mathrm{d}=\text { is the depth or thickness of the material }\end{array}$ \\
\hline
\end{tabular}

\section{Mechanical Properties Tests}

To measure the ability of basalt to withstand repeated impact loading, all samples were tested for calculating unconfined (uni-axial) compressive strength (UCS). The rocks have UCS that ranges between 98.5 and $106.9(\mathrm{MPa})$ and averages $101.26(\mathrm{MPa})$. The values were used to classify these rocks using Deere and Miller (1966) chart. All samples (Table 4) lie in field C thus pointing out that the samples are medium strength. W max (\%) ranges from 1.4-1.55 and an average of $1.44(\%)$. The $\mathrm{Wn}(\%)$ ranges from $0.25-0$ to $0.45(\%)$ and average $0.34(\%)$. 
Table 3. Physical properties of the Umm Al-Jamal basalts

\begin{tabular}{|c|c|c|c|c|c|c|}
\hline $\begin{array}{l}\text { Core } \\
\text { number }\end{array}$ & $\begin{array}{l}\text { Specific } \\
\text { gravity } \\
\text { (GSB) }\end{array}$ & $\begin{array}{c}\text { Apparent } \\
\text { specific } \\
\text { gravity } \\
\text { (GSA) }\end{array}$ & $\begin{array}{c}\text { Absorption } \\
(\%)\end{array}$ & $\begin{array}{c}\text { Porosity } \\
(\%)\end{array}$ & $\begin{array}{c}\text { Dry unit } \\
\text { weight } \\
\left(\mathrm{gm} / \mathrm{cm}^{3}\right)\end{array}$ & $\begin{array}{c}\text { Ultrasonic } \\
\text { wave } \\
\text { velocity }(\mathrm{m} / \mathrm{s})\end{array}$ \\
\hline H 1 & 2.87 & 2.73 & 0.82 & 1.13 & 2.60 & 4644 \\
\hline H 2 & 2.75 & 2.69 & 0.94 & 1.20 & 2.59 & 4398 \\
\hline H 3 & 2.71 & 2.62 & 1.58 & 0.96 & 2.58 & 4842 \\
\hline $\mathrm{H} 4$ & 2.79 & 2.71 & 1.51 & 0.84 & 2.59 & 4274 \\
\hline $\mathrm{H} 5$ & 2.72 & 2.64 & 0.96 & 1.17 & 2.60 & 4856 \\
\hline H 6 & 2.71 & 2.62 & 1.14 & $1 . .11$ & 2.61 & 4203 \\
\hline H 7 & 2.68 & 2.61 & 1.69 & 1.55 & 2.65 & 4534 \\
\hline H 8 & 2.67 & 2.54 & 1.66 & 0.87 & 2.67 & 4613 \\
\hline H 9 & 2.75 & 2.64 & 1.27 & 1.23 & 2.58 & 4223 \\
\hline H 10 & 2.72 & 2.63 & 1.57 & 1.18 & 2.60 & 4557 \\
\hline Range & $2.67-2.87$ & $2.54-2.73$ & $0.82-1.66$ & $0.84-1.11$ & $2.58-2.67$ & $4613-4842$ \\
\hline Average & 2.73 & 2.64 & 1.27 & 1.46 & 2.6 & 4514 \\
\hline
\end{tabular}
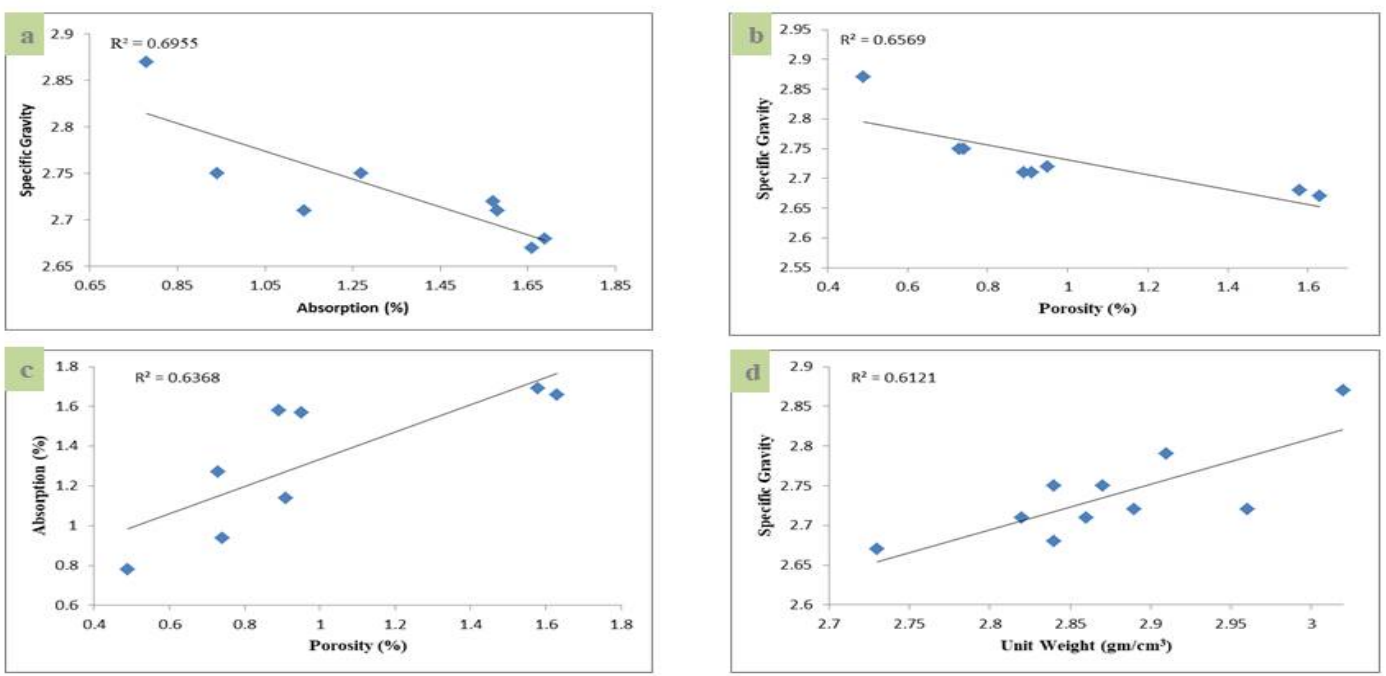

Fig. 3. (a) Specific gravity and absorption (\%) diagram, (b) Specific gravity and porosity (\%) diagram, (c)Absorption and porosity (\%) diagram and (d) Specific gravity and unit weight $\left(\mathrm{gm} / \mathrm{cm}^{3}\right)$ diagram 


\section{Mechanical properties tests}

To measure the ability of basalt to withstand repeated impact loading, all samples were tested for calculating unconfined (uni-axial) compressive strength (UCS). The rocks have UCS that ranges between 98.5 and $106.9(\mathrm{MPa})$ and averages $101.26(\mathrm{MPa})$. The obtained values were used to classify these rocks using Deere and Miller (1966) chart. All samples (Table 4) lie in field $\mathrm{C}$ thus pointing out that the samples are medium strength. Moreover, $\mathrm{W}$ max (\%) ranges from 1.4-1.55 and average of $1.44(\%)$. The Wn (\%) ranges from $0.25-0$ to $0.45(\%)$ and average $0.34(\%)$. Slake durability test was carried out on each sample in two cycles were calculated and the results are listed in Table (4). This table shows that the different samples are with values $>99 \%$. Based on the classification of ISRM (1978), the Umm Al-Jamal samples can be classified as highly durable. The results of the Los angles abrasion value tests of basalt aggregates show no big differences are from all tested samples. The calculated abration ratio of (100/500) shows an of $0.25 \%$ which is classified as medium strength, class C. According to El-Hasan and Al-Malabeh (2008) and Al-Malabeh and Kempe (2009) the high resistance of these rocks to abrasion can be attributed to the high volume percentage of olivine and pyroxene minerals. A high posivtive correlation of slake durability (\%) with $\mathrm{W}$ $\max (\%)$, Fig. 4.b, with $\mathrm{R}^{2}=0.87$. While slake durability (\%) show a negative correlations with UCS (MPa) and and Los Angeles $(\%) \mathrm{R}^{2}=-0.51$ and $\mathrm{R}^{2}=-0.91$, respectively, Figs. 5.c. and 4.c. Finally, slake durability shows a slightly positive correlations with unit weight $(\mathrm{gm} / \mathrm{cm} 3)$, $\mathrm{R}^{2}=0.51$, Fig. 5.d. The flexure strength (MPa) ranges from 29-23.5 (MPa) and averages $30.02(\mathrm{MPa})$. These values with the corresponding equivalent of UCS (MPa) were calculated using the relation developed by Broch and Franklin (1972). The tested samples are categorized as a strong flexure strength (MPa) shows negative correlations with UCS (MPa), $\mathrm{R}^{2}=-0.69$, Fig. 5b. Indirect tensile strength (MPa) intended results show no big differences and the values range between 9.5 and 10.9 $\mathrm{MPa}$ and averages 10.3 MPa. UCS (MPa) has a slight positive correlation and slake durability (MPa), with $\mathrm{R}^{2}=0.55$ Fig. $4 \mathrm{~d}$. Also, tensile strength $\mathrm{MPa}$, shows a slightly positive correlation with flexure strength (MPa) and a high positive correlation abrasion values with $\mathrm{R}^{2}=0.67$, and $\mathrm{R}^{2}=0.84$, respectively, Figures (4a and 5a). The physical and mechanical properties of the available stone, basalt are the main determinant in choosing between one technique and another. The most widely structural systems used in the Umm Al-Jamal to span architectural spaces is corbelling technique (AlMalabeh, 1996 and Rababeh et al., 2010). Therefore, it is also recommended to take this study in consideration in any conservation at the Umm Al-Jaml archaeological city. 
Table 4. Basalt rock tests results of Slake durability, W max, Los Angeles, tensile strength, compressive strength, and flexural tensile strength

\begin{tabular}{|c|c|c|c|c|c|c|c|}
\hline $\begin{array}{c}\text { Core } \\
\text { number }\end{array}$ & $\begin{array}{c}\text { Slake } \\
\text { durability } \\
(\mathbf{\%})\end{array}$ & $\begin{array}{c}\text { Wmax } \\
\mathbf{( \% )}\end{array}$ & $\begin{array}{c}\text { Wn } \\
\mathbf{( \% )}\end{array}$ & $\begin{array}{c}\text { Los Angeles } \\
\mathbf{( \% )} \\
\mathbf{( 1 0 0 / 5 0 0 )}\end{array}$ & $\begin{array}{c}\text { Tensile } \\
\text { strength } \\
\mathbf{( M P a )}\end{array}$ & $\begin{array}{c}\text { Uni-axial } \\
\text { compressive } \\
\text { strength } \\
(\mathbf{M P a})\end{array}$ & $\begin{array}{c}\text { Flexure } \\
\mathbf{( M P a )}\end{array}$ \\
\hline H 1 & 99.2 & 1.5 & 0.36 & 0.23 & 10 & 99.1 & 29.3 \\
\hline H 2 & 99.1 & 1.45 & 0.45 & 0.24 & 10.3 & 99.8 & 29.6 \\
\hline H 3 & 99 & 1.43 & 0.25 & 0.27 & 10.5 & 100 & 30.8 \\
\hline H 4 & 99.3 & 1.55 & 0.41 & 0.21 & 9.5 & 98.5 & 29 \\
\hline H 5 & 99.05 & 1.44 & 0.31 & 0.26 & 10.3 & 99.9 & 29.5 \\
\hline H 6 & 99 & 1.42 & 0.33 & 0.26 & 10.3 & 102.1 & 29.5 \\
\hline H 7 & 98.95 & 1.4 & 0.37 & 0.27 & 10.5 & 105.5 & 30.7 \\
\hline H 8 & 98.8 & 1.4 & 0.34 & 0.28 & 10.9 & 106.9 & 32.5 \\
\hline H 9 & 99.1 & 1.45 & 0.35 & 0.24 & 10.3 & 99.8 & 29.5 \\
\hline H 10 & 99.05 & 1.44 & 0.29 & 0.25 & 10.4 & 101 & 29.8 \\
\hline Range & $98.8-99.3$ & $1.4-1.55$ & $0.25-0.45$ & $0.21-0.28$ & $9.5-10.9$ & $98.5-106.9$ & $29-32.5$ \\
\hline Average & 99.055 & 1.448 & 0.346 & 0.251 & 10.3 & 101.26 & 30.02 \\
\hline
\end{tabular}
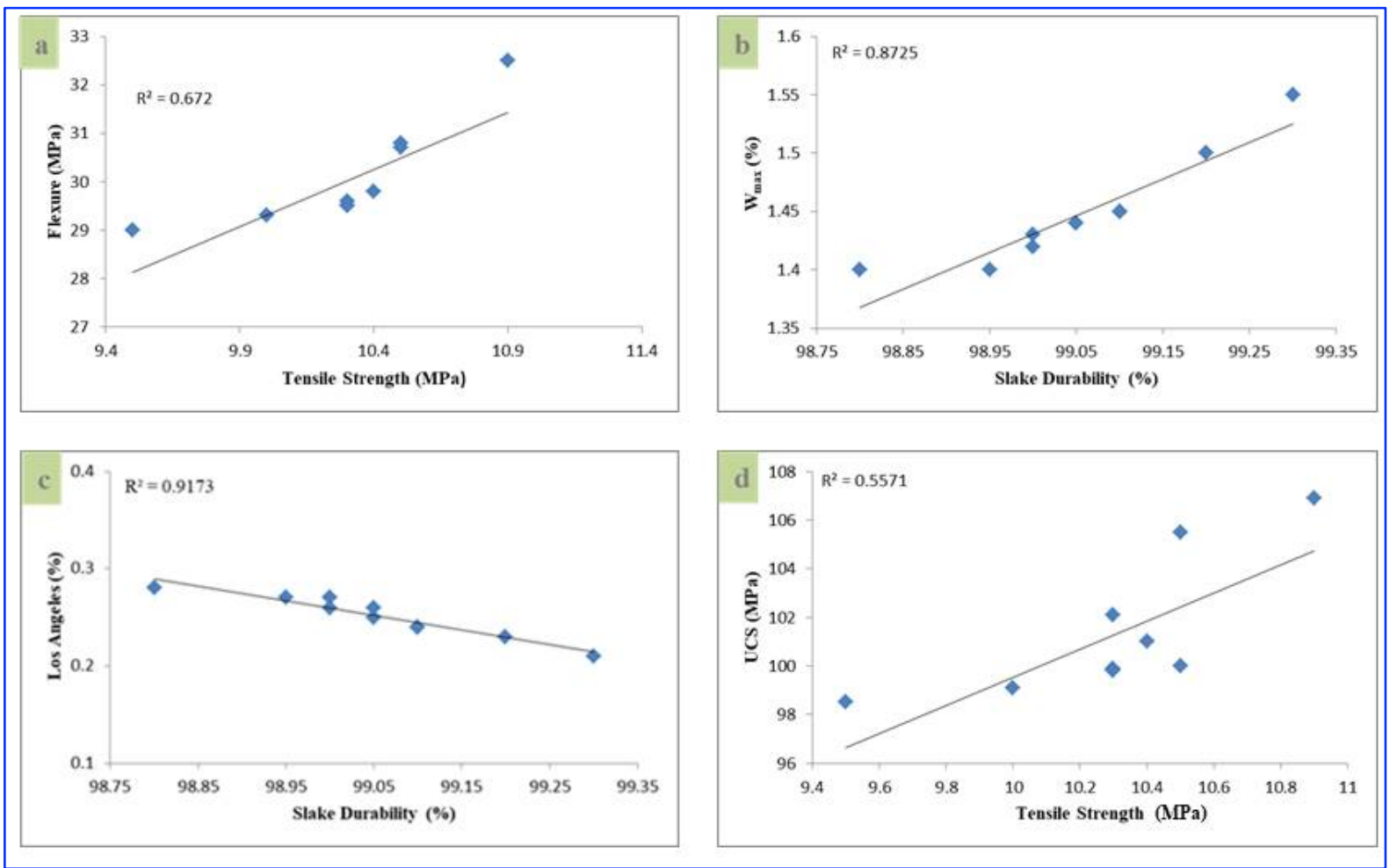

Fig. 4. (a) Tensile strength (MPa) and flexure (MPa) diagram, (b) Slake durability (\%) and $W_{\max }(\%)$ digram, (c) Slake durability (\%) and Los Angeles (\%) diagram and (d) UCS (MPa) and tensile (MPa) diagram 


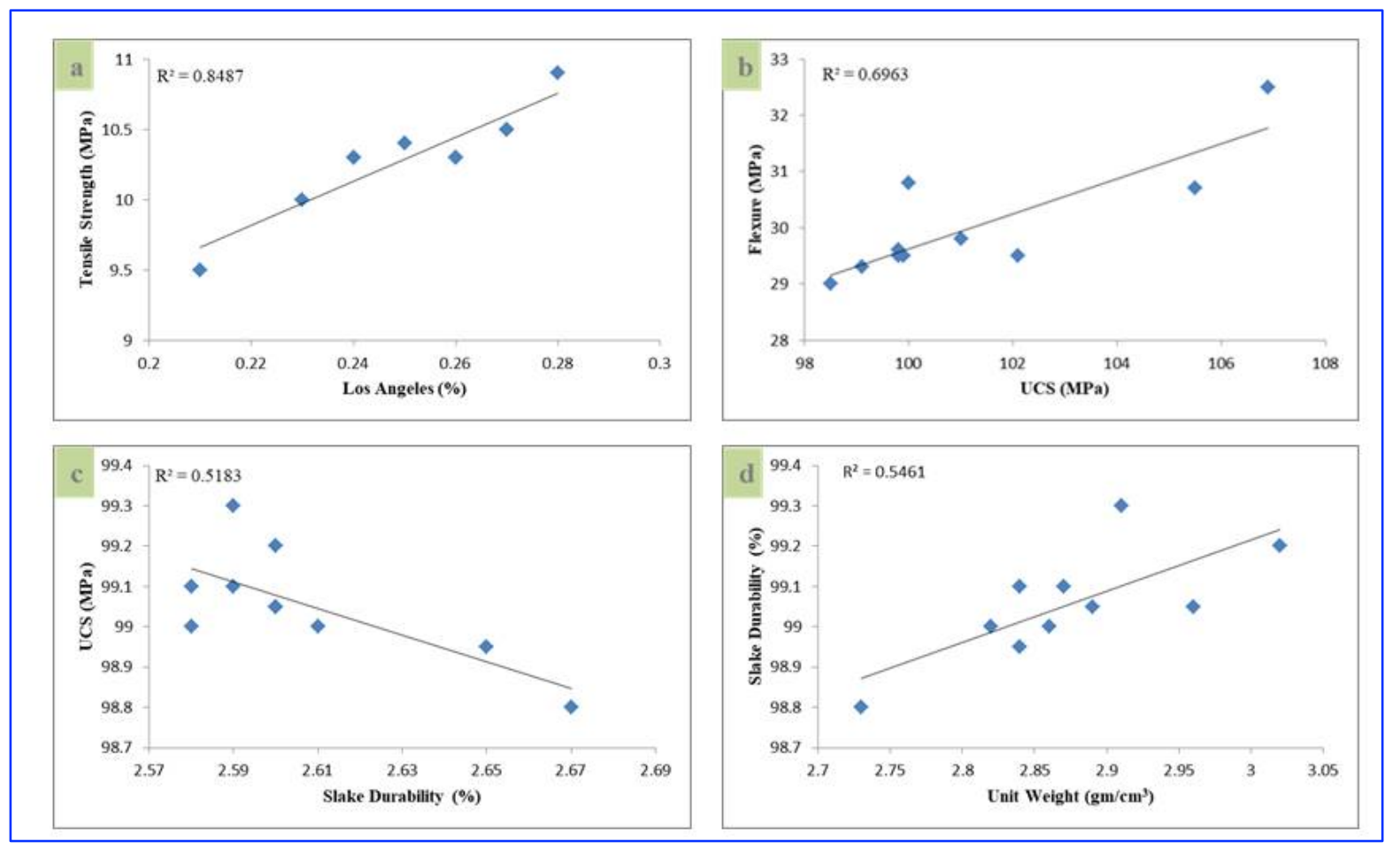

Fig. 5. (a) Loss Angeles (\%) and tensile strength (MPa) diagram, (b) Flexture (MPa) and UCS (MPa) diagram, (c) Slake durability and UCS (MPa) and (d) Unit weight $\left(\mathrm{gm} / \mathrm{cm}^{3}\right)$ and slake durability $(\%)$ diagram

\section{CONCLUSIONS}

The following conclusions can be drawn from this study:

1. The Umm Al-Jamal basalts cover an area of about $10 \mathrm{~km}^{2}$. It was developed due to intermittent eruption from deep-seated faults in form of 5 successive basaltic pahoehoe flows with a total thickness of $50 \mathrm{~m}$.

2. The Umm Al-Jamal basaltic rocks have relatively high bulk specific gravity (2.602.84), high apparent specific gravity (2.54-2.73), low absorption (\%) (0.33-1.60\%) and high unit weight $\left(2.58-2.67 \mathrm{gm} / \mathrm{cm}^{3}\right)$. This indicates the cohesive nature of the rocks. Porosity has an average of $1.46 \%$, which relataled to class $\mathrm{C}$ of medium porous, based on rock classification criterion given by Jumikis (1983). The uniaxial strength (98.5-105.5 MPa) and tensile strength (9.5-10.9 MPa). Depends on the classification system suggested by Deere and Miller (1966), the rocks are classified as of medium strength rocks, class $\mathrm{C}$. The results of slake durability indicate gigh durable. The calculated abration ratio of $100 / 500$ shows ratio of $0.25 \%$ which is classified as medium strength, class $\mathrm{C}$.

3. The basalt samples 100/500ified according to the IAEG (1986), as high ultrasonic wave velocity indicates that they are classified as class 4 , which has an average of 
$4514 \mathrm{~m} / \mathrm{s}$. Porosity $2.67 \%$ gives high porous basalt depends on Jumikis (1983) description. They have a high unit weight that averages $1910 \mathrm{~kg} / \mathrm{m}^{3}$.

4. The physico-mechanical tests of the rocks are fitting well with the classification schemes of the international specifications(e.g. ASTM, 2008, ISMR, 1978 and IAEG, 1986), This study strongly recommends using the studied basaltic rocks in some industrial applications, e.g, as normal aggregate and dimension stones in construction. Therefore it is recommended to take this study in consideration in any conservation or restoration processes at the Umm Al-Jaml archaeological site.

\section{ACKNOWLEDGEMENTS}

The authors thank the technical staff of the Department of Civil Engineering, Jordan University of Science and Technology for their help in the engineering tests.

\section{REFERENCES}

Abu-Mahfouz, I., Al-Malabeh, A. and Rababeh, S., 2016. Geo-engineering evaluation of Harrat Irbid basaltic rocks, Irbid District- North Jordan, Arab Journal of Geoscience, 9: 412.

Al-Malabeh, A., 1993. The volcanology, mineralogy and geochemistry of selected pyroclastic cones from NE- Jordan and their evaluation for possible industrial applications, Ph.D. thesis, Erlangen University, Germany.

Al-Malabeh, A. and Kempe, S., 2009. Petrolithology of permian melaphyre lava of the Dieburger Straße Tunnel, Darmstadt, Germany. J. Neues Jahrbuch fuer Geologie und Palaeontologie, 252: 129-143.

Al-Malabeh, A. and Al-Kharabsheh, A., 2002. Economic evaluation of scoria volcanic rocks from Northern Badia Region (basaltic plateau), Jordan and their possible use as construction materials. Proceeding of Congress in Urban Developments in Arid region \& Associated Problems, 3: 173-185.

Al-Malabeh, A., 1994. Geochemistry of two volcanic cones from the intra-continental plateau basalt of Harra El-Jabban, NE-Jordan. Basaltic rocks of various tectonic settings, Special Issue of the Geochemical Journal, Japan, 28: 542-558.

Al-Malabeh, A., 1996. The physical, mechanical properties, industrial evaluation and economic of scoria deposits from Harrat El-Jabban, NE-Jordan. 30th Intr. Geol. Cong, Abstr., 3:3, Beijing, China.

Al-Malabeh, A., 2010. Volcanic successions of the Jebal Remah volcano, Northeast Jordan. International Journal of Economic and Environment Geology, 1:6-10.

Al-Malabeh, A., El-Hasan, T., Lataifeh, M. and O'Shea, M., 2002. Geochemical- and mineralogicalrelated magnetic characteristics of the tertiary-quaternary (Umm A-Qutein) basaltic Flows from the basaltic field of Harra El-Jabban, Northeast Jordan. Physica B-Physics of Condensed Matter, 321: 396403.

ASTM (American Society for testing and materials), 2008. Soils and Rocks $(1,2)-$ D 4543-85. Annual book of ASTM standards, Philadelphia.

Barberi, F., Capaldi, G., Gasperini, P., Marinelli, G., Santacroce, R., Scandone, R., Treuil, M. and Varet, J., 1979. Recent basaltic volcanism of Jordan and Its implications on the geodynamic evolution of the AfroArabian rift system". Academia Nazionale Dei Lincei, Att Del Convegni Lincei, 667-683.

Broch, E. and Franklin, A., 1972. The point load strength test. International Journal of Rock Mechanics and Mining Sciences and Geomatics, 9(6): 669-697.

Brown, E., 1981. Rock Characterization Testing and Monitoring. Pergamon Press, Ltd. London

Camp, E. and Roobol, J., 1989. The arabian continental alkali basalt province: Part 1. Evolution of Harrat Rahat, Kingdom of Saudi Arabia: Bulletin of the Geological Society of America, 101: 71-95.

Coleman, R. and Mc Guire, A., 1988. Magma systems related to the Red Sea opening. Tectonophysics, 150:77-100.

Deere, D., and Miller, R., 1966. Engineering classification and index properties of intact rock. Tech report. No. AFWL-Tr-65-116, USAF Weapons lab. Kirtland Air force Base, NM.

Derucher, K., and Heins, C., 1981. Materials for Civil and High Way Engineers. Prentice Hall, Inc. New York.

El-Hasan, T. and Al-Malabeh, A., 2008. Geochemistry, mineralogy and petrogenesis of El-Lajjoun 
pleistocene alkali basalt of central Jordan, Jordan Journal of Earth \& Environmental Sciences, 2: 1-15.

Farmer, I., 1983. Engineering Behavior of Rocks, 2nd edn. Chapman and Hall Ltd., London.

IAEG (Internation association for engineering geology), 1986. Rock mechanics tests. Proceedings of the international symposium on engineering geology problems. Paris.

ISRM (Internation society for rocks mechanics), 1978. Suggested methods for the quantitativedescription of discontinuities in rock mechanics. Mechanics and minig sciences \& geomechanica abstracts, 15: 319-368.

Jumikis, A., 1983. Rock Mechanics Edition (Series On Rock and Soil Mechnics). 2nd ed. Book. Trans Tech Publications.

Obert, L. and Duvall, W., 1966. Rock Mechanics and The Design of Structures in Rock. John Wiley and Sons,Inc. New York.

Rababeh, S., El-Mashaleh, M., and Al-Malabeh, A., 2010. Factors determining the choice of the building techniques Petra, Jordan, International Journal Architectural Heritage, 6: 1-50.

Roobol, M., Pint, J., Al-Shanti, M, Al-Juaid, A., Al-Amoudi, S., and Pint, S., Al-Eisa, A., Allam, F., AlSulaimani, G., and Banakhar, A., 2002. Preliminary survey for lava-tube caves on Harrat Kishb, Kingdom of Saudi Arabia., Saudi Geological Survey, 3: 35.

Smadi, A., Al-Malabeh, A and Odat, S., 2018. Characterization and origin of selected basaltic outcrops in Harrat Irbid (HI), northern jordan. Jordan Journal of Earth \& Environmental Sciences, 9:185-196.

Touloukian, Y., William R. and Robert F., 1981. Physical Properties of Rocks and Minerals, McGraw-Hill, New York. 